\title{
Ingestive behaviour of grazing ewes given two levels of concentrate
}

\author{
T.P.D. Silva ${ }^{1,2 \#}$, C.A.T. Marques ${ }^{2}$, J.N.C. Torreão², L.R. Bezerra², M.J. Araújoº ${ }^{2}$, F.P. Gottardi ${ }^{2}$, \\ R.L. Edvan ${ }^{2} \&$ R.L. Oliveira ${ }^{3}$ \\ ${ }^{1}$ Centre of Nuclear Energy in Agriculture, University of São Paulo, São Paulo State, Brazil \\ ${ }^{2}$ Department of Zootecnia, Federal University of Piauí, Bom Jesus, Piauí State, Brazil \\ ${ }^{3}$ School of Veterinary and Zootecnia/UFBA, Salvador, Bahia State, Brazil
}

(Received 19 February 2014; Accepted 2 March 2015; First published online 13 June 2015)

\begin{abstract}
Copyright resides with the authors in terms of the Creative Commons Attribution 2.5 South African Licence.
See: http://creativecommons.org/licenses/by/2.5/za

Condition of use: The user may copy, distribute, transmit and adapt the work, but must recognise the authors and the South African Journal of Animal Science.
\end{abstract}

\begin{abstract}
This study aimed to evaluate the influence of concentrate supplementation on the ingestive behaviour of grazing ewes. Twelve pregnant pluriparous sheep were used, six of the Santa Inês breed and six of the Morada Nova breed. The supplement was formulated to supply the animals with two feed levels $(0.5 \%$ and $1.5 \%$ of body weight) of nutrition. The experimental design was a randomized $2 \times 2 \times 2$ factorial arrangement (two breeds, two supplementation levels and two feeding shifts, morning and afternoon) with six replicates per treatment, totalling 24 experimental units. Focal sampling was used to record the time spent on the adopted behaviour at 10-minute intervals for 10 continuous hours, with three replications, totalling 180 records per animal. Sampling started at 07:00. Time spent grazing, ruminating and resting did not correlate with the level of concentrate supplementation. It was expected that concentrate supplementation would reflect directly on forage intake owing to the substitution effect, which causes sheep where the supplement supplied a small proportion of net energy requirement, to have a greater grazing intensity. The two breeds differed in the time spent ruminating or lying, with the Santa Inês sheep spending more time in these activities. Greater intensity of grazing and ruminating occurred in the morning, which is directly related to the climatic conditions of the region. Time of day is a factor that imposes limitations on the feeding behaviour patterns of ewes that are supplemented on pasture.
\end{abstract}

Keywords: Breed, grazing, Morada Nova, Santa Inês, season

\#Corresponding author: tairon.mvet@gmail.com

\section{Introduction}

The success of a production system for grazing ruminants is affected by changes in feeding behaviour. Under unfavourable conditions of pasture intake, a decrease in dry matter (DM) ingestion may occur. Knowledge of the feeding behaviour of grazing animals facilitates appropriate strategies for pasture and animal management, and the ability to intervene positively with production results (Hao et al., 2013).

Food shortages and poor quality of feed are the most limiting factors for livestock production, both for quality and characteristics of production, including cost. Therefore, the study of ingestive behaviour of ewes in grazing systems deserves special attention (França et al., 2009), especially since a semi-arid environment is one of the major agro-ecological zones of the tropics. In Brazil, over $50 \%$ of the sheep population is concentrated in this type of environment, which gives rise to strong relationships between agro-climatic conditions, population density, cropping systems and livestock production (Maurya et al., 2010). In addition, the development of sheep production may have a direct influence on the income and quality of life of part of the population (Renaudeau et al., 2012; Shiotsuki et al., 2014).

Choice of breed is a determining factor in the success of a production system. Research into this area has found that, in general, the daily activities of sheep include alternating periods of grazing, ruminating and idling. The intensity and distribution of these activities are influenced by a number of factors such as the availability and nutritive value of the pasture and its management, the activity of animals in the group as well as predominant climatic conditions of the region (Silva et al., 2008).

The supply of concentrated supplements for grazing ruminants can influence production and animal behaviour by stimulating or inhibiting the intake of material, because the response to the type of supplements 
in terms of energy and protein causes changes in the behaviour of animals, thus influencing their performance (Camilo et al., 2013).

The patterns of ingestive behaviour of ruminants can influence the digestion of food and its rate of passage through the gastrointestinal tract. Animals can change their behaviour if one or more components of food is modified, to overcome the limiting conditions for intake and to consume the required amount of nutrients (Pompeu et al., 2009). Information on the behaviour of grazing animals during the day and under different management conditions is scarce. The semi-arid region is characterized by high temperatures because of the high incidence of solar radiation, low humidity and high evaporation. Its main feature is the scarcity and irregularity in the distribution of rainfall. A combination of these factors can cause intense discomfort to animals (Silva et al., 2013) and interfere with pasture availability and grazing time, causing inefficiency of the production system. However, ruminant animals find it easy to adapt to varying conditions of feeding, handling and setting, by modifying feeding behaviour to achieve a level of intake that is compatible with nutritional requirements, especially that of energy.

Thus, understanding the behaviour of the grazing animal receiving concentrate supplementation may enable improved bio-economic indices of production in grazing systems. The aim of this study was to evaluate the influence of concentrate supplementation on ingestive behaviour of grazing ewes.

\section{Materials and Methods}

The experiment was conducted in March to April 2011 at the Research Unit on Small Ruminants, Campus Professor Cinobelina Elvas (CPCE), Federal University of Piauí (FUPI), Bom Jesus-PI (latitude $09^{\circ}$ $04^{\prime} 28$ " S and longitude $44^{\circ}$ 21'31" W) at an altitude of 277 metres above sea level. The research protocol followed the guidelines of the Ethical Committee for Animal Experimentation of the Federal University of Piauí (ECAE/UFPI), number 091/2010.

Twelve pregnant pluriparous ewes were used, six of the Santa Ines breed and six of the Morada Nova breed. The ewes were in the final third of gestation, with an average initial body weight (BW) ( \pm standard deviation) of $52.6 \pm 6.54$ and $31.3 \pm 3.74 \mathrm{~kg}$, respectively. To ensure that all ewes were at the same stage of pregnancy, oestrus was synchronized for nine days with an intravaginal sponge containing $60 \mathrm{mg}$ of medroxyprogesterone acetate (Progespon ${ }^{\circledR}$ Syntex S.A, Argentina). After sponge removal, at the beginning of the follicle-stimulating hormone treatment, $200 \mathrm{UI}$ of equine chorionic gonadotropin (Folligon $5000 \AA$, Intervet, Holanda) and $0.1 \mathrm{mg}$ of cloprostenol sodium (Ciosin ${ }^{\circledR}$, Intervet, Holanda) were given by intramuscular injection to synchronize the follicular wave and to stimulate ovulations. After oestrous synchronization the ewes were artificially inseminated at a fixed time with Dorper semen. Thirty days after artificial insemination, a pregnancy diagnosis was performed through trans-abdominal ultrasound, and pregnant ewes were selected from each genetic group. During the experimental period, the sheep remained from 07:00 to 17:00 in a pasture paddock of Andropogon grass (Andropogon gayanus) under continuous grazing, in an area of 1.8 hectares (ha) and approximately 0.44 animal units (AU)/ha. They were rounded up in late afternoon and allocated to individual pens measuring $1.75 \mathrm{~m}^{2}$. There they received a supplemental concentrate consisting of ground maize (70\%), soybean meal (25\%) and a mineral supplement (5\%) (Table 1) at $0.5 \%$ or $1.5 \%$ of body weight (BW). This was adjusted weekly. The experiment lasted 42 days, with 20 days as adaptation.

Table 1 Chemical composition of the ingredients of the concentrate, the concentrate supplement and Andropogon grass (Andropogon gayanus)

\begin{tabular}{lrrrrrrrr}
\hline & \multicolumn{8}{c}{ Chemical composition (g/kg DM) } \\
\cline { 2 - 8 } & DM & CP & EE & TDN & NDF & ADF & Ca & P \\
\hline Ingredients & & & & & & & & \\
$\quad$ Maize meal & 871.9 & 99.8 & 51.9 & 675.0 & 245.5 & 58.7 & 0.5 & 4.9 \\
$\quad$ Soybean meal & 884.8 & 487.6 & 17.5 & 807.3 & 153.7 & 96.4 & 3.3 & 5.7 \\
$\quad$ Mineral mixture & 979.1 & - & - & - & - & - & 180.0 & 130.0 \\
Supplement & 880.4 & 191.7 & 40.6 & 674.3 & 210.2 & 65.1 & 9.0 & 11.3 \\
Andropogon grass & 274.5 & 75.0 & 20.2 & 535.6 & 747.0 & 419.7 & 3.3 & 1.1 \\
& & & & & & & & \\
\hline
\end{tabular}

DM: dry matter; CP: crude protein; EE: ether extract; TDN: total digestible nutrients; Ca: calcium; P: phosphorus.

${ }^{1}$ Mineral mixture: $1600 \mathrm{mg}$ zinc; $600 \mathrm{mg}$ copper; $1500 \mathrm{mg}$ manganese; $1100 \mathrm{mg}$ iron; $10 \mathrm{mg}$ cobalt; $27 \mathrm{mg}$ iodine and $22 \mathrm{mg}$ selenium. 
The concentrate supplement was formulated according to the recommendations of the NRC (2007) for pregnant ewes. It was confirmed that the total requirements of protein and metabolizable energy were 146 $\mathrm{g} /$ day and $16.15 \mathrm{MJ} /$ day, respectively. At the supplemental level of $1.5 \% \mathrm{BW}$ the concentrate provided approximately $70 \%$ of daily requirements. Thus, the animals were subjected to two levels of nutrition: one in which the nutritional requirement of net energy was undersupplied (supplemented at $0.5 \%$ of the BW); and another in which it was oversupplied (supplemented with 1.5\% BW), on an "as is" basis.

Analyses of DM, crude protein (CP), ether extract (EE), neutral detergent fibre (NDF), acid detergent fibre (ADF), calcium (C) and phosphorus $(P)$ in the concentrate and forage were performed according to the procedures described by Silva \& Queiroz (2002).

To estimate total forage availability, three pasture samples were collected, each on the same day of monitoring the ingestive behaviour. For this the pasture was randomly divided into five areas within the paddocks, using a metallic square of $1.0 \mathrm{~m}^{2}(1.0 \times 1.0 \mathrm{~m})$. Samples from each square were weighed and divided into sub-samples, which were then used to form composite samples in duplicate per period, packed in plastic bags, identified and frozen to assess the total availability of DM. From each pair of forage samples, one was used to separate the green leaves, green colm (stem), dry leaves and dried colm, which were weighed, stored in plastic bags, frozen and subsequently analysed to determine chemical characteristics. The other sub-sample was used to evaluate the chemical composition of the material. The mass of leaf and stem material was determined by separating and quantifying the dry weight of each component. The samples were weighed fresh, placed in a forced-air oven, and kept for $72 \mathrm{~h}$ at $55^{\circ} \mathrm{C}$ to quantify the dry weight.

To evaluate the chemical composition of the forage consumed by the animals, samples were collected via manual simulation of grazing. Samples and chemical analyses were processed at the Laboratory of Animal Nutrition of CPCE-UFPI. The determination of potentially digestible dry matter (DMPD) was subsequently performed according to the method of Paulino et al. (2005):

$$
\mathrm{DM}_{\mathrm{PD}}(\% \mathrm{DM})=\{0.98 \times(100-\mathrm{NDF})\}+(\mathrm{NDF}-\mathrm{iNDF})
$$

where NDF $=$ neutral detergent fibre $(\% \mathrm{DM})$ and iNDF $=$ indigestible neutral detergent fibre (\% DM). iNDF was determined according to the methodology described by Casali et al. (2009).

Averages of meteorological variables were obtained from a surface automatic weather station and are presented in Table 2.

The focal sampling method was used to record the time spent on the adopted behaviour at 10-minute intervals for 10 continuous hours with three replications (days) at weekly intervals, always starting at 07:00 and ending at 17:00, totalled 30 hours of evaluation, and 180 records per animal, according to the methodology described by Johnson \& Combs (1991). Ingestive behaviour was considered mutually exclusive, because for each record, each animal was classified on only one activity (Carvalho et al., 2004). From these data, the average times spent eating, ruminating and resting were analysed. The number of times the animal walked, defecated and urinated was also noted.

The experimental design was a randomized $2 \times 2 \times 2$ factorial arrangement of two breeds (Santa Inês and Morada Nova), two supplementation levels ( $0.5 \%$ and $1.5 \% \mathrm{BW})$, and two periods (morning and afternoon) with six replications per treatment, totalling 24 experimental units. Data were analysed using analysis of variance, and the means were compared by Tukey's test at 5\% probability. The experimental data were analysed using SAS (2003), according to the statistical model:

$Y_{i j k}=\mu+B_{i}+S_{j}+(B S)_{(i j)}+P_{k}+(B P)_{(i k)}+(B S P)_{(j \mathrm{jk})}+e_{(j \mathrm{jk})}$, where:

$Y_{\mathrm{ijk}}=$ value observed for characteristic analysed

$\mu=$ overall average

$B_{i}=$ effect of breed $I=1,2$

$S_{j}=$ effect of level of concentrate supplementation $j=1,2$

$\mathrm{T}_{\mathrm{k}}=$ effect of period $\mathrm{k}=1,2$

$\mathrm{BS}_{(\mathrm{ij})}=$ effect of the interaction between breed $\mathrm{i}$ and level of concentrate supplementation $\mathrm{j}$

$B T_{(i k)}=$ effect of the interaction between breed $\mathrm{i}$ and period $\mathrm{k}$

$\mathrm{BST}_{(\mathrm{jk})}=$ effect of the interaction between breed $\mathrm{i}$, level of concentrate supplementation $\mathrm{j}$, and collection period $\mathrm{k}$

$\mathrm{e}_{\mathrm{b}(\mathrm{j} \mathrm{jk})}=$ random error associated with the observation $Y_{\mathrm{ijk} \text {. }}$ 


\section{Results and Discussion}

In the data analysis of temperature and relative humidity, afternoon conditions were outside the thermo-neutral zone and within the effective upper critical limit of $35^{\circ} \mathrm{C}$ (Baêta \& Sousa, 2010). Relative humidity is directly and inversely related to temperature; therefore when there is an increase in air temperature, there is a reduction in relative humidity (Table 2 ).

Table 2 Averages of meteorological variables and indices of temperature and humidity as recorded by the weather station during the trial period

\begin{tabular}{lcc}
\hline \multirow{2}{*}{ Variables } & \multicolumn{2}{c}{ Period } \\
\cline { 2 - 3 } & Morning & Afternoon \\
\hline Air temperature $\left({ }^{\circ} \mathrm{C}\right)$ & $22.7^{\mathrm{b}} \pm 1.59$ & $30.6^{\mathrm{a}} \pm 1.74$ \\
Relative humidity $(\%)$ & $90.9^{\mathrm{a}} \pm 6.13$ & $59.3^{\mathrm{b}} \pm 8.80$ \\
Index of temperature and humidity & $72.0^{\mathrm{b}} \pm 2.12$ & $78.9^{\mathrm{a}} \pm 1.18$ \\
\hline
\end{tabular}

a, b Means in the row with different superscripts differ significantly at $P<0.05$.

Heat stress was classified by Armstrong (1994) according to the index of temperature and humidity as mild (72 - 78), moderate (79 - 88) and severe (89 - 98). Values below 72 do not characterize thermal stress. Thus, afternoon conditions were unfavourable for grazing animals, shortening the time compared with mornings. Pereira et al. (2014) stated that climatic conditions of the Gurguéia Valley region produced significant changes in the physiological parameters of Morada Nova and Santa Inês sheep on concentrate supplementation, which can affect the behaviour patterns of these sheep owing to the heat increment. Eustáquio Filho et al. (2011) reported that an environment with a temperature of $25^{\circ} \mathrm{C}$ and a humidity of $65 \%$ reflects the best conditions of comfort for sheep and animal productivity.

In terms of availability of pasture (Figure 1) for pregnant sheep in this study, there was considerable production of herb mass with greater proportions of leaves and green stems than leaves and dry leaves, favouring a higher rate of digestibility. This higher rate leads to better utilization of nutrients by rumen microorganisms and better sheep nutrition, especially during the final third of gestation, which is the period of greatest demand and of greatest foetal development (Van Soest, 1994).

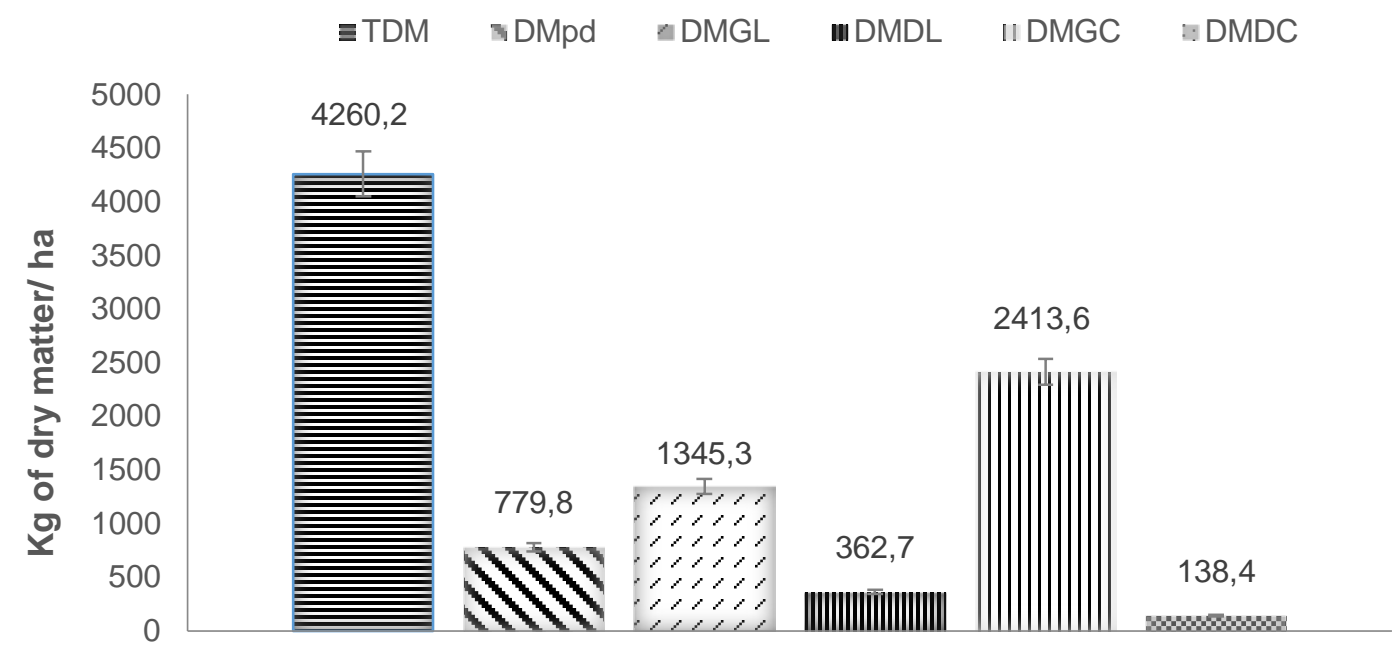

Forage mass

Figure 1 Mean values of availability of total dry matter (TDM), potentially digestible dry matter (DMpd), dry matter of green leaf (DMGL), dry matter of dried leaf (DMDL), dry matter of green culm (DMGC) and dry matter of dried culm (DMDC), during the experimental period. 
In an experiment performed by Menezes et al. (2010), sheep that have been supplemented with concentrates and allowed to graze on Andropogon grass (Andropogon gayanus) during drought, had lower production performance than sheep grazing Aruana (Panicum maximum cv. Aruana) and Tanzãnia grass (Panicum maximum). Thus, in the modal system of the region under study, animal performance is limited not only by the reduced amount of leaf mass, but also by the low nutritional value of the forage, emphasizing the need for supplementation during the transition period. In the current research no significant $(P<0.05)$ interacting effects were found between breed $x$ supplementation level, breed $x$ period and breed $x$ supplementation level $x$ period in ingestive behaviour.

Confortin et al. (2010) reported that patterns of animal feeding behaviour under diets supplemented or unsupplemented depend on the structural characteristics of the pasture to which they are subjected throughout the grazing period. Therefore, grazing time was not affected $(P>0.05)$ by supplementation (Table $3)$. In general, ewes subjected to the two supplementation levels ( 0.5 and $1.5 \% \mathrm{BW}$ ) showed similar behavioural activities, possibly owing to an excess of rumen-degradable protein in the supplement, causing them to resort to the pasture to compensate for the excess protein and maintain a good protein : fermentable carbohydrate ratio to maintain homeostasis in the rumen. The data of this study corroborate those of McManus et al. (2011).

Table 3 Influence of concentrate supplementation on ingestive behaviour (hours) of grazing ewes during pregnancy

\begin{tabular}{lcccccccc}
\hline \multirow{2}{*}{ Treatments } & \multicolumn{8}{c}{ Activities } \\
\cline { 2 - 9 } & GRAZ & RUMF & RUML & STAN & LYIN & WALK & URI & DEF \\
\hline $0.5 \%$ BW & 5.92 & 0.92 & 0.86 & 1.1 & 0.38 & 0.78 & 0.02 & 0.02 \\
$1.5 \%$ BW & 5.98 & 0.89 & 0.83 & 1.18 & 0.35 & 0.77 & 0.00 & 0.00 \\
SEM & 0.31 & 0.24 & 0.02 & 0.04 & 0.12 & 0.02 & 0.01 & 0.01 \\
$P$ value & ns & ns & ns & ns & ns & ns & ns & ns \\
& & & & & & & & \\
\hline
\end{tabular}

ns: not significant $(P>0.05)$.

GRAZ: grazing; RUMF: ruminating on foot; RUML: ruminating lying down; STAN: standing idle; LYIN: lying idle; WALK: walking; URI: urinating; DEF: defecating; BW: bodyweight; SEM: standard error of the mean.

Since concentrate supplementation was expected to reflect directly on forage intake owing to the substitution effect, the sheep receiving the low level of supplementation showed a greater grazing intensity in this study. These results disagree with those of Confortin et al. (2010) in a study in which ewes were supplemented. They reported a reduction in diurnal grazing time and increased time devoted to other activities, although patterns of intake, displacement and demand were unchanged. In the current study, rumination time was not affected $(P>0.05)$ by supplementation, regardless of the manner in which the animals ruminated, either standing or lying down, which was expected, because grazing behaviour did not differ between treatments (Table 3). According to Pompeu et al. (2009), sheep subjected to different supplementation levels spent more time ruminating on foot in order to dissipate the excessive heat caused by high daytime temperatures, which is different from the results of the present study. Other variables evaluated in this study were not affected by the level of supplementation $(P>0.05)$.

Feeding behaviour between breeds was found not to be statistically different $(P>0.05)$ in time spent grazing (Table 4). High adaptive capability to the semi-arid environment (Silva et al., 2015), can explain the great similarity in the grazing patterns between these breeds. Also, development of grazing habits in this environment could explain the great similarity in the grazing patterns between these breeds.

The time spent grazing and its intensity are closely related not only to the morphological characteristics of grass, the time spent on grass seizure and on reducing grass particles, but also to the characteristics of the concentrated feed supplement. However, the frequency of feeding and rumination is related to the feeding habits of each species and can vary between breeds (Li, 2013). The time spent ruminating lying down was significantly different $(P<0.05)$ between breeds. The Santa Inês sheep spent more time on this activity (Table 4). Periods spent on feed intake are interspersed with one or more periods of rumination or idleness, and the supply of feed influences the rate of rumination, which is higher at night. Differences between individuals in the duration and division of activities may be conditioned by the appetite 
of the animals, their anatomy, and supply of energy, which would be affected by the forage : concentrate ratio (Fischer et al., 2000).

Table 4 Effect of breed on feeding behaviour (hours) of grazing ewes subjected to concentrate supplementation during pregnancy

\begin{tabular}{lcccccccc}
\hline \multirow{2}{*}{ Breed } & \multicolumn{8}{c}{ Activities } \\
\cline { 2 - 9 } & GRAZ & RUMF & RUML & STAN & LYIN & WALK & URI & DEF \\
\hline Morada Nova & $5.90^{\mathrm{a}}$ & $0.62^{\mathrm{a}}$ & $0.90^{\mathrm{b}}$ & $1.5^{\mathrm{a}}$ & $0.28^{\mathrm{a}}$ & $0.58^{\mathrm{a}}$ & $0.02^{\mathrm{a}}$ & $0.02^{\mathrm{a}}$ \\
Santa Inês & $5.96^{\mathrm{a}}$ & $0.68^{\mathrm{a}}$ & $1.36^{\mathrm{a}}$ & $1.1^{\mathrm{b}}$ & $0.32^{\mathrm{a}}$ & $0.58^{\mathrm{a}}$ & $0.00^{\mathrm{a}}$ & $0.00^{\mathrm{a}}$ \\
SEM & 0.14 & 0.03 & 0.09 & 0.08 & 0.09 & 0.02 & 0.004 & 0.007 \\
$P$ value & $\mathrm{ns}$ & $\mathrm{ns}$ & $*$ & $*$ & $\mathrm{~ns}$ & $\mathrm{~ns}$ & $\mathrm{~ns}$ & $\mathrm{~ns}$
\end{tabular}

${ }_{\mathrm{a}, \mathrm{b}}$ Means in the column with different superscripts differ significantly at $P<0.05\left(^{*}\right)$, ns: not significant $(P>0.05)$.

GRAZ: grazing; RUMF: ruminating on foot; RUML: ruminating lying down; STAN: standing idle; LYIN: lying idle; WALK: walking; URI: urinating; DEF: defecating; BW: bodyweight; SEM: standard error of the mean.

In addition, changes in feed intake can be verified through evaluating feeding behaviour and reflect directly on animal productivity. However, new techniques for modifying feeding behaviour alter not only the feed, but also the physical and metabolic characteristics of the animal. Thus, patterns of behaviour reflect the adaptation of animals to various environmental factors and may indicate methods for improving animal productivity through different management systems. The activity of standing idle differed $(P<0.05)$ among genetic groups; Morada Nova sheep spent more time not performing any activity, as reflected in other variables seen in Table 4. This behaviour is possibly because of the search for greater dissipation of heat produced via the heat increment of the diet and environmental conditions. The impact of these factors becomes more pronounced in animals raised on pasture because their interaction can cause intense physiological disturbances (Sijean et al., 2010; Silva et al., 2013; Rocha et al., 2014).

In terms of the effects of shift on the behaviour of sheep grazing, greater intensity of grazing occurred in the morning $(P<0.05)$ (Table 5$)$, which is related directly to climatic conditions. The region has high solar radiation during the afternoon, combined with a decrease in relative humidity, which greatly influences the feed intake by ruminants, and therefore their productive functions. Thus, the morning is more favourable for grazing and greater herbage intake by the animals, as observed in this study.

Table 5 Effect of time of day on behaviour (hours) of grazing ewes receiving concentrate supplementation during pregnancy

\begin{tabular}{lcccccccc}
\hline \multirow{2}{*}{ Periods } & \multicolumn{8}{c}{ Activities } \\
\cline { 2 - 9 } & GRAZ & RUMF & RUML & STAN & LYIN & WALK & URI & DEF \\
\hline \multirow{2}{*}{ Morning } & $3.49^{\mathrm{a}}$ & $0.32^{\mathrm{a}}$ & $0.25^{\mathrm{a}}$ & $0.44^{\mathrm{b}}$ & $0.07^{\mathrm{b}}$ & $0.42^{\mathrm{a}}$ & $0.01^{\mathrm{a}}$ & $0.00^{\mathrm{a}}$ \\
Afternoon & $2.72^{\mathrm{b}}$ & $0.23^{\mathrm{b}}$ & $0.20^{\mathrm{b}}$ & $0.89^{\mathrm{a}}$ & $0.56^{\mathrm{a}}$ & $0.40^{\mathrm{a}}$ & $0.00^{\mathrm{a}}$ & $0.00^{\mathrm{a}}$ \\
SEM & 0.23 & 0.14 & 0.08 & 0.03 & 0.03 & 0.01 & 0.003 & 0.001 \\
$P$ value & $*$ & $*$ & $*$ & $*$ & $*$ & $n s$ & $n$ ns & ns \\
& & & & & & & &
\end{tabular}

${ }^{\mathrm{a}, \mathrm{b}}$ Means in the column with different superscripts differ significantly at $\left.P<0.05{ }^{*}\right)$, ns: not significant $(P>0.05)$. GRAZ: grazing; RUMF-ruminating on foot; RUML: ruminating lying down; STAN: standing idle; LYIN: lying idle; WALK: walking; URI: urinating; DEF: defecating; BW: bodyweight; SEM: standard error of the mean.

Oliveira et al. (2013) evaluated the behaviour of Santa Ines sheep subjected to an environment with and without shade, and found that the number of animals in the sun was reduced by $20 \%$ during the hottest times of the day, coinciding precisely with the period in which there was greater variation in the global 
temperature index. The highest grazing intensity was observed in the early morning and late afternoon, probably because these times present mild bioclimatic conditions, which may favour higher intake by grazing animals with a lower rate of caloric increase.

Significant effects $(P<0.05)$ were found regarding rumination, both standing and lying down, with the morning being greater for both breeds. This behaviour may be because of the influence of heat transfer from the environment to the animal, with a lesser effect on the production of heat (Pines \& Phillips, 2013).

Idleness was considered the period in which the animals remained standing without performing any activity. The time in which the animals remained idle while standing or lying was greater $(P<0.05)$ in the afternoon than in the morning. Possibly the high solar radiation was unfavourable to grazing activity. This phenomenon was reported by Zanine et al. (2006), who asserted that sheep prefer to stay idle during the hottest hours, mainly because of better energy utilization of feed and an increase in the dissipation of heat.

\section{Conclusions}

The ingestive behaviour of ewes on pasture during pregnancy was not affected by the level of concentrate supplementation. However, their behavioural activities were influenced by breed and period. Santa Inês ewes spent more time ruminating lying down and Morada Nova ewes expended more time standing idle. In addition, a higher intensity of grazing and ruminating occurred in the morning, which is related directly to the climatic conditions of the region.

\section{References}

Armstrong, D.V., 1994. Heat stress interaction with shade and cooling. J. Dairy Sci. 77, 2044-2050.

Baêta, F.C. \& Souza, C.F., 2010. Ambiência em edificações rurais: Conforto animal. $2^{\mathrm{a}}$ ed. Viçosa: Universidade Federal de Viçosa, 246 p. (in Portuguese).

Camilo, D.A., Pereira, E.S., Pimentel, P.G., Oliveira, R.L., Cândido, M.J.D., Costa, M.R.G.F. \& Aquino, R.M.S., 2013. Intake and feeding behaviour of Morada Nova lambs fed different energy levels. Ital. J. Anim. Sci. 11, 13-19.

Carvalho, G.G.P., Pires, A.J.V., Silva, F.F., Veloso, C.M., Silva, R.R., Silva, H.G., Bonomo, P. \& Mendonça, S.S., 2004. Comportamento ingestivo de cabras leiteiras alimentadas com farelo de cacau ou torta de dendê. Pesq. Agrop. Bras. 39, 919-925. (in Portuguese).

Casali, A.O., Detmann, E., Valadares Filho, S.C., Pereira, J.C., Cunha, M., Detmann, K.S.C.D. \& Paulino, M.F., 2009. Estimação de teores de componentes fibrosos em alimentos para ruminantes em sacos de diferentes tecidos. Rer. Bras. Zootec. 38, 130-138. (in Portuguese).

Confortin, A.C.C., Bremm, C., Rocha, M.G., Silva, J.H.S., Elejalde, D.D.G., Camargo, D.G. \& Rosa, A.T.N., 2010. Padrões de comportamento ingestivo de cordeiras recebendo ou não suplemento em pastagem de milheto. Ciênc. Rural. 40, 2555-2561. (in Portuguese).

Eustáquio Filho, A., Teodoro, S.M., Chaves, M.A., Santos, P.E.F., Silva, M.W.R., Murta, R.M., Carvalho, G.P. \& Souza, L.E.B., 2011. Zona de conforto térmico de ovinos da raça Santa Inês com base nas respostas fisiológicas, Rev. Bras. Zoot. 40, 1807-1814. (in Portuguese).

Fischer, V., Dutilleul, P., Deswysen, A.G., Dèspres, L. \& Lobato, J.F.P., 2000. Aplicação de probabilidade de transição de estado dependente do tempo na análise quantitativa do comportamento ingestivo de ovinos. Rev. Bras. Zootec. 29, 1811-1820. (in Portuguese).

França, S.R.L., Gonzaga Neto, S., Pimenta Filho, E.C., Medeiros, A.N., Torreão, J.N.C., Mariz, T.M.A. \& Costa, R.G., 2009. Comportamento ingestivo de ovelhas Morada Nova no terço final de gestação com níveis de energia metabolizável na dieta. Rev. Bras. Saúde Prod Anim. 10, 73-84. (in Portuguese).

Hao, J., Dickhoefera, U., Lina, L., Müllera, K., Glindemanna, T., Schönbachb, P., Schiborrab, A., Wanga, C. \& Susenbetha, A., 2013. Effects of rotational and continuous grazing on herbage quality, feed intake and performance of sheep on a semi-arid grassland steppe. Arch. Anim. Nutr. 67, 62-76.

Johnson, T.R. \& Combs, D.K., 1991. Effects of prepartum diet, inert rumen bulk, and dietary polythylene glycol on dry matter intake of lactating dairy cows. J. Dairy Sci. 74, 933-944.

$\mathrm{Li}, \mathrm{Z}$., 2013. Sex-age related rumination behavior of Pe're David's deer under constraints of feeding habitat and rainfall. Plos One. 8:e66261. doi:10.1371/journal.pone.0066261

Maurya, V.P., Sejian, V., Kumar, D. \& Naqvi, S.M.K., 2010. Effect of induced body condition score differences on sexual behavior, scrotal measurements, semen attributes, and endocrine responses in Malpura rams under hot semi-arid environment. J. Anim. Phys. Anim. Nutrit. 94, 308-317.

McManus, C., Louvandini, H., Paim, T.P., Martins, R.S., Barcellos, J.O.J., Cardoso, C., Guimarães, R.F. \& Santana, O.A., 2011. The challenge of sheep farming in the tropics: aspects related to heat tolerance. R. Bras. Zootec. 40, 107-120.

Mendonça, S.S., Campos, J.M.S., Valadares Filho, S.C., Valadares, R.F.D., Soares, R.F.D., Lana, R.P., Queiroz, A.C., Assis, A.J. \& Pereira, M.L.A., 2004. Comportamento ingestivo de vacas leiteiras 
alimentadas com dietas à base de cana-de-açúcar ou silagem de milho. Rev. Bras. Zootec. 33, 723728. (in Portuguese).

Menezes, L.F.O., Louvandini, H., Martha Júnior, G.B., Mcmanus, C., Barroso, G.G.J.E. \& Mendes, M.C.B., 2010. Desempenho de ovinos Santa Inês suplementados em três gramíneas pastejadas durante o período seco. Arch. Zootec. 59, 299-302. (in Portuguese).

NRC, 2007. Nutrient Requirements of Sheep. National Academic Press, Washington, DC, USA.

Oliveira, M.E.F., Sousa, H.L.L., Moura, A.C.B., Vicente, W.R.R., Rodrigues, L.F.S. \& Araújo, A.A., 2013. The effects of parturition season and suckling mode on the puerperium of Santa Ines ewes and on the weight gain of lambs. Arqu. Bras. Med. Vet. Zootec. 65, 857-864.

Paulino, M.F., Moares, E.H.B.K. \& Zervoudakis, J.T., 2005. Fontes de energia los suplementos múltiplos de auto-regulação de consumo na recria de novilhos mestiços los pastagem de Brachiaria decumbens de durante das período águas. Rev. Bras. Zootec. 3, 957-962. (in Portuguese).

Pereira, A.M., Bonifácio, A.M.R., Santos, C.V., Silva, I.A., Silva, T.P,D., Sousa, K.R.S., Gottardi, F.P., Marques, C.A.T. \& Torreão, J.N.C., 2014. Thermoregulatory traits of native sheep in pregnancy and supplemented in grazing system. J. Agric. Sci. 6,113-119.

Pines, M.K. \& Phillips, C.J.C., 2013. Microclimatic conditions and their effects on sheep behavior during a live export shipment from Australia to the Middle East. J. Anim. Sci. 91, 4406-4416.

Pompeu, R.C.F.F., Rogério, M.C.P., Cândido, M.J.D., Neiva, J.N.M., Guerra, J.L.L. \& Gonçalves, J.S., 2009. Comportamento de ovinos em capim-tanzânia sob lotação rotativa com quatro níveis de suplementação concentrada. Rev. Bras. Zootec. 38, 374-383. (in Portuguese).

Renaudeau, D., Collin, A., Yahav, S., Basilio, V., Gourdine, J.L. \& Collier, R.J., 2012. Adaptation to hot climate and strategies to alleviate heat stress in livestock production. Animal 6, 707-728.

Rocha, R.R., Santos, P.B., Nunes, A.G., Silva, T.P.D., Pereira, A.M. \& Torreão, J.N.C., 2014. Adaptive parameters and thermal comfort of postpartum ewes fed on concentrate supplementation in grazing system. Acta Sci. Anim. Sci. 36, 317-321.

SAS, 2003. SAS System for Windows, Release 9.1. SAS Inst., Inc., Cary, NC, USA.

Sejian, V., Maurya, V.P., Naqvi, S.M.K., Kumar, D. \& Joshi, A., 2010. Effect of induced body condition score differences on physiological response, productive and reproductive performances of Malpura ewes kept in a hot, semi-arid environment. J. Anim. Phys. Anim. Nutr. 94, 154-161.

Shiotsuki, L., Oliveira, D.P., Lôbo, R.N.B. \& Facó, O., 2014. Genetic parameters for growth and reproductive traits of Morada Nova sheep kept by smallholder in semi-arid Brazil. Small Rumin. Res., 120, 204-208.

Silva, D.J. \& Queiroz, A.C., 2002. Análise de alimentos - Métodos químicos e Biológicos. Viçosa. Universidade Federal de Viçosa. (in Portuguese).

Silva, R.R., Prado, I.N., Carvalho, G.G.P., Santana Junior, H.A., Silva, F.F. \& Dias, D.L.S., 2008. Efeito da utilização de três intervalos de observações sobre a precisão dos resultados obtidos no estudo do comportamento ingestivo de vacas leiteiras em pastejo. Ciên. Anim. Bras. 9, 319-326. (in Portuguese).

Silva, T.P.D., Sousa Júnior, S.C., Santos, K.R., Marques, C.A.T. \& Torreão, J.N.C., 2013. Características termorreguladoras e ganho de peso de cordeiros Santa Inês no sul do estado do Piauí no período de transição seca/águas. Agrarian 6, 198-204. (in Portuguese).

Silva, T.P.D., Marques, C.A.T., Torreão, J.N.C., Araújo, M.J., Bezerra, L.R., Rocha, A.M. \& Sousa, S.V., 2015. Intake and some indicators of the metabolic status of native ewes in pregnancy and supplemented in grazing system. Afr. J. Agric. Res. 10, 200-206.

Van Soest, P.J., 1994. Nutritional Ecology of the Ruminant. 2 ed. Ithaca: Cornell University Press, USA. $476 \mathrm{p}$.

Zanine, A.M., Andrade, S.I., Pereira Filho, M.J. \& Silva, A.M.A., 2006. Comportamento ingestivo de ovinos e caprinos em pastagens de diferentes estruturas morfológicas. Rev. Eletr. Vet. 7, 1-10. (in Portuguese). 